\title{
$\mathrm{ADI}$ 材の高サイクル疲労き裂発生・進展寿命分布特性と寿命評価
}

\author{
越 智 保 雄* 小 方 智 寿** \\ 久保田 祐 信***石 井 明*

\section{Initiation and Propagation Life Distributions of Fatigue Cracks and the Life Evaluation in High Cycle Fatigue of ADI}

by

\author{
Yasuo Ochi ${ }^{*}$, Tomohisa Ogata ${ }^{* *}$, Masanobu Kubota ${ }^{* * *}$ \\ and Akira IsHII ${ }^{*}$
}

Rotating bending fatigue tests were carried out on austempered ductile cast iron (ADI) in order to investigate the statistical properties of life distributions of crack initiation and propagation, and also the evaluation of fatigue life.

The results are summarized as follows: (1) The size of crack initiation sites of the material was represented by. a Weibull distribution without regarding to the kinds of crack initiation sites such as microshrinkage and graphite grain. The crack initiation life scattered widely, but the scatter became much smaller as soon as the cracks grew. (2) The crack propagation life $N_{a c}$ which was defined as the minimum crack propagation rate showed lower scatter than the crack initation life. (3) The fatigue life of the material was evaluated well by $N_{a c}$ and the propagation rate after $N_{a c}$. It was clear that the fatigue life of ductile cast iron was goverened by the scatter of $N_{a c}$.

Key words : Fatigue, Crack initiation, Life distribution, Weibull distribution, Austempered ductile cast iron

\section{1 緒袞}

球状黒鉛鋳鉄（以下 DI 材）は高強度，高じん性， 優れた鋳造性や耐摩耗性といった多くの特長のために，

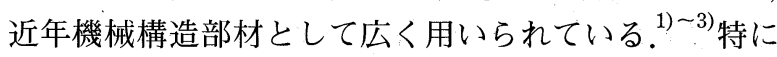
本研究の供試材であるオーステンパ处理球状黒鉛鋳鉄 (Austempered Ductile Cast Iron, 以下 ADI) は他の DI 材と比較して高い強度とじん性を有し，DI 材の中 でも注目されている材料である。

前報 ${ }^{6)}$ では, $\mathrm{ADI}$ 材の詳細な疲労き裂の発生起点の観 察をもとに起点形状の定量的評価と分布状況の検討を行 い，さらに微小き裂の発生・進展特性に及ぼす影響につ いても考察した。そこでは $\mathrm{ADI}$ 材の起点やき裂の進展 挙動に，著者らが今までに行うたフェライト基地とパー ライト基地球状黒鉛鋳鉄（FDI，PDI）と異なった特性 があることが明らかとされた. DI 材の疲労寿命や疲労 強度は, 基地組織中に存在する黒鉛や微小引け巣のよう な鋳造欠陥によって大きなばらつきを有するために，疲 労を考慮すべき部材の使用には，供試材に応じたき裂の 発生・進展特性を充分把握することが必要である。
そこで本研究では，前報を踏まえて $\mathrm{ADI}$ 材の寿命分 布の確率特性を検討し，発生初期寿命分布に進展特性 を考慮した疲労寿命分布の評価を試みた。これと同時に FDI，PDI の表面き裂の発生・進展特性および破断寿

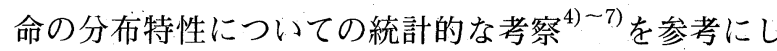
て，基地組織とも関連した DI 材の疲労寿命分布特性 についても考察した。

\section{2 実 験 方 法}

\section{$2 \cdot 1$ 供試材}

供試材はオーステンパ処理球状黒鉛鋳鉄で，化学成分 および機械的性質を，比較を行った FDI，PDI 材と共に Table I に示した.オーステンパ処理は，オーステンパ温 度 $880 \sim 900^{\circ} \mathrm{C}$, ソルトバス温度 $320 \sim 380^{\circ} \mathrm{C} て ゙$ 時間はそ れぞれ 2 時間という条件で行った。微視組織および黒鉛 性状を Fig. 1，Table II に示した。黒鉛性状の測定では， 黒鉛粒径が $10 \mu \mathrm{m}$ 未満の黒鉛は除外した。微視組織は 黒鉛と基地組織である針状のオースフェライト組織から なっている. FDI, PDI 材の黒鉛性状と比較すると, 黒 鉛平均粒径, 球状化率に大差はない.

Table I. Chemical compositions and mechanical properties.

\begin{tabular}{c|c|c|c|c|c|c|c|c|c|c|c|c|c}
\hline & $\mathrm{C}$ & $\mathrm{Si}$ & $\mathrm{Mn}$ & $\mathrm{P}$ & $\mathrm{S}$ & $\mathrm{Mg}$ & $\mathrm{Cu}$ & $\mathrm{Cr}$ & $\mathrm{Mo}$ & $\sigma_{B}[\mathrm{MPa}]$ & $\sigma_{Y}[\mathrm{MPa}]$ & $\delta[\%]$ & $\mathrm{HB}$ \\
\hline ADI & 3.76 & 2.15 & 0.32 & 0.019 & 0.009 & 0.042 & 0.62 & 0.04 & 0.02 & 699 & 954 & 13.9 & 273 \\
\hline FDI & 3.76 & 2.21 & 0.19 & 0.017 & 0.016 & 0.038 & - & - & - & 260 & 396 & 25.1 & 129 \\
\hline PDI & 3.70 & 2.13 & 0.34 & 0.013 & 0.008 & 0.038 & 0.62 & 0.04 & - & 476 & 819 & 8.0 & 255 \\
\hline
\end{tabular}

$\dagger \quad$ 原稿受理 平成 9 年 1 月10日 Received Jan. 10, 1997

* 正会員 電気通信大学機械制御工学科 广182 調布市調布ヶ丘, Dept. of Mech. \& Control Eng., Univ. of Electro Communications, Chofugaoka, Chofu, 182

** 日立金属(株)素材研究所 †321-43 真岡市鬼怒ヶ丘, Casting Technology Res. Lab., Kinu-ga-oka, Mooka, 321-43

*** 正会員 九州大学工学部機械工学科 $=812$ 福岡市東区箱崎, Dept. of Mech. Sci. and Eng. Kyushu Univ., Higashi-ku, Fukuoka, 812 


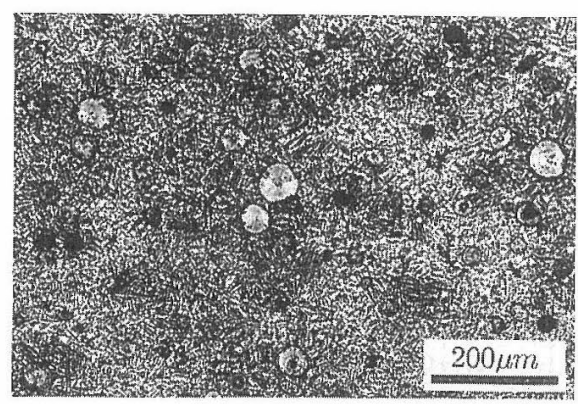

Fig. 1. Microstructure.

Table II. Characteristics of microstructure

\begin{tabular}{lc|c|c|c}
\hline & & ADI & FDI & PDI \\
\hline Ausferrite area fraction & {$[\%]$} & 100 & - & - \\
\hline Ferrite area fraction & {$[\%]$} & - & 100 & 12.8 \\
\hline Pearlite area fraction & {$[\%]$} & &.- & 87.2 \\
\hline Graphite grain size & {$[\mu \mathrm{m}]$} & 31.1 & 32.3 & 31.8 \\
\hline Nodularity(area method) & {$[\%]$} & 84.0 & 84.8 & 86.8 \\
\hline Graphite area fraction & {$[\%]$} & 12.4 & 14.1 & 14.6 \\
\hline Nodule count in a unit area & {$\left[1 / \mathrm{mm}^{2}\right]$} & 147 & 141 & 174 \\
\hline
\end{tabular}

\section{$2 \cdot 2$ 疲学試験方法}

疲労試験は, 小野式回転曲げ疲労試験機（約 $3000 \mathrm{cpm}$ )を用い，室温・大気中で行った。試験片は Fig. 2 に示すような寸法・形状で, 中央に浅い円周切り 达み学入した。寿命分布の確率的な取扱いでは試験片 寸法も重要な用件であるので, 前報と重複するが示した。 試験中適宜，試験機を停止してレプリカ法によって表面 微小き裂を観察した。またレプリカは SEM 観察と合わ せて痩労き裂の発生起点の特定のためにも用いた。

Fig. 3 に- $N$ 曲線を示した。これより， $\mathrm{ADI}$ 材の疫労 限度は $\sigma_{w}=340 \mathrm{MPa}$ と推定された。表面き裂の発生・ 進展特性の比較のために, 応力振幅 $\sigma_{a}=440 \mathrm{MPa}$ (以 下, 高応力レベル), $360 \mathrm{MPa}$ (低応力レベル) のそれぞ れで14本前後の実験を行った。それぞれの応力振幅は 1 $\times 10^{5}$ 扎よび $5 \times 10^{5}$ の繰返しで破断する応力として定義 した。このときの応力振幅 $\sigma_{a}$ は破断寿命たけでなく FDI, PDI の $\sigma_{a} / \sigma_{w}$ の值と近くなるように定めた。痏労 限度と実験条件をまとめて Table IIIに示した。眓中の破 線および一点鎖線で示した $N_{i}$ は後述の定義によるき裂 発生寿命を表している。

\section{2・3 各寿命の定義}

き裂発生寿命 $N_{i}$ は表面き裂長さが $2 a_{i}=80 \mu \mathrm{m}$ に達し た繰返し数で定義した。破断寿命 $N_{f}$ は，き裂長さ $2 a$ が $3000 \mu \mathrm{m}$ を越えると進展が非常に早くなりき裂の追跡

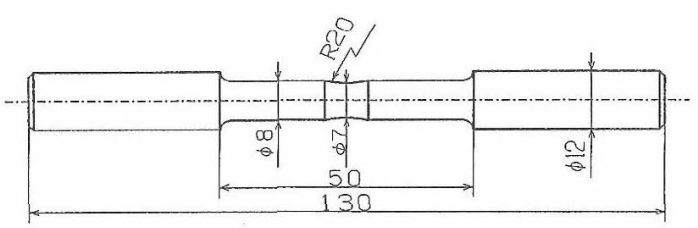

Fig. 2. Shape of specimen.

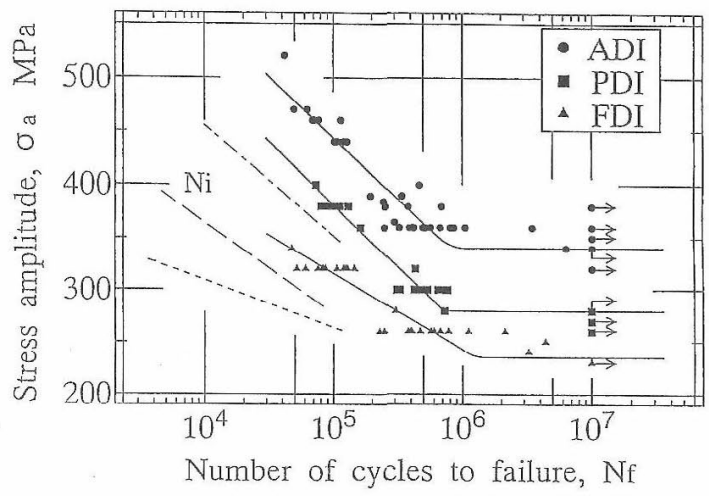

Fig. 3. S-N curves.

Table III. Fatigue limits and test conditions.

\begin{tabular}{c|c|c|c|c|c}
\hline & \multirow{2}{*}{$\begin{array}{c}\text { Fatigue } \\
\text { limit }\end{array}$} & \multicolumn{2}{|c|}{$\begin{array}{c}\text { High stress level } \\
\left(N_{f}=1 \times 10^{5}\right)\end{array}$} & \multicolumn{2}{c}{$\begin{array}{c}\text { Low stress level } \\
\left(N_{f}=5 \times 10^{5}\right)\end{array}$} \\
\cline { 3 - 6 } & $\begin{array}{c}\sigma_{a} \\
{[\mathrm{MPa}]}\end{array}$ & $\sigma_{a} / \sigma_{w}$ & $\begin{array}{c}\sigma_{a} \\
{[\mathrm{MPa}]}\end{array}$ & $\sigma_{a} / \sigma_{w}$ \\
\hline ADI & 340 & 440 & 1.3 & 360 & 1.1 \\
\hline FDI & 235 & 320 & 1.4 & 260 & 1.1 \\
\hline PDI & 280 & 380 & 1.4 & 300 & 1.1 \\
\hline
\end{tabular}

が困難となることを考慮して, $2 a=3000 \mu \mathrm{m}$ に達した繰 返し数と定義した。き裂進展寿命は，破断寿命から発生 寿命を差引いたものではなく，ここではき裂の発生から 破断に至る過程を一連の連続した過程としてとらえるた めに，上と同様に一定の表面さ裂長さで定義した。ここ では破断寿命の $50 \%$ 小よび $75 \%$ にあたる 2 つのき裂進展 寿命を定義して，学れ资れ $N_{p 1}, N_{p 2}$ とした。 $N_{p 1}, N_{p 2}$ の時の表面さ裂長さは， $2 a_{p 1}=400 \mu \mathrm{m}, 2 a_{p 2}=1000 \mu \mathrm{m}$ である。これらの定義は，前報 ${ }^{4)}$ 万) と同様であるのでそ ららを参照されたい。

\section{3 実験結果および考察}

\section{$3 \cdot 1$ き裂発生寿命と起点寸法の関連}

$\mathrm{ADI}$ 材の初期き裂進展特性について詳細に観察した前 報 $^{6)}$ によって，ADI 材の起点には黒鉛と微小引け坚やド ロスのような微小鋳造欠陌があることが分かっている。 Fig. 4 は起点となった黒鉛, 微小欠陥の寸法を破面上の 面積の平方根 $\sqrt{\text { area }}$ でワイブル確率紙にプロットしたも のである。起点の $\sqrt{\text { area }}$ はほぼ直線上に並んでおり，1

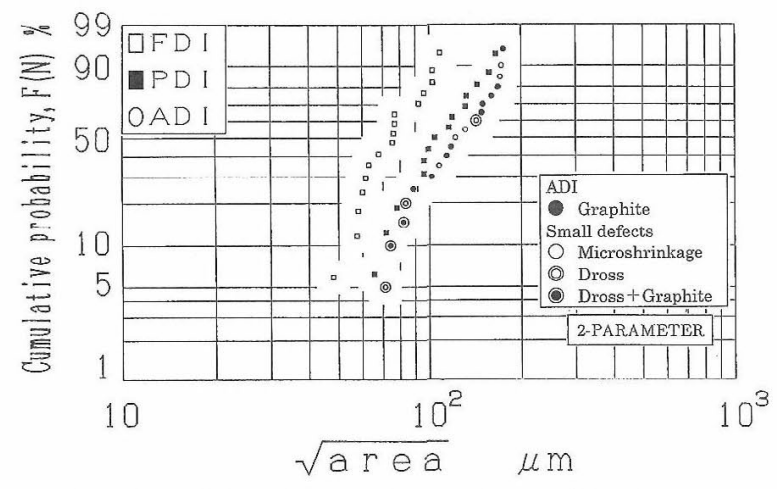

Fig. 4. Weibull plot of size of small defects or spheroidal graphites observed at fracture origin. 


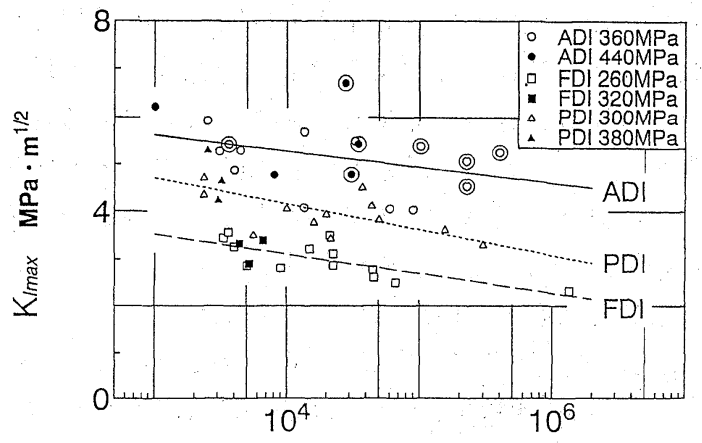

Number of cycles, $\mathrm{Ni}$

Fig. 5. Relation between $K_{\text {Imax }}$ and $N_{i}$.

つの 2 母数ワイブル分布で表示できることが分かる。こ れは ADI 材のき裂の発生が, 起点が黒鉛であるか微小 引け巣であるかということによらず，その大きさによっ てのみ支配されていることを表している.

そこで，き裂の発生寿命 $N_{i}$ をき裂長さ $2 a=80 \mu \mathrm{m}$ に達 した繰返し数で定義して起点寸法との関連を検討した が, $\sqrt{\text { area }}$ と $N_{i}$ の相関は低く, ADI 材のき裂発生寿命 は起点寸法だけでは整理できないことが分かった．このた め表面き裂の発生に対する起点が表面に存在する場合, 表 面直下に存在する場合の影響を考慮して，Fig. 5 に $K_{\text {Imax }}$ と $\sqrt{\text { area }} に よ る$ 整理を試みた結果を示した， $K_{\text {Imax }}$ は，起 点部を任意形状のき裂と見なした時のき裂前縁の応力拡 大係数の最大值であり, 村上らの方法 ${ }^{8)}$ によって求めた。 欠陥が表面に接する場合と欠陥が表面から離れた内部に存 在する場合に分けて，それぞれ以下の式で得た.

$$
\begin{gathered}
K_{\text {Imax }}=0.650 \sigma_{a} \sqrt{\pi \sqrt{\text { area }}} \\
K_{\text {Imax }}=0.5 \sigma_{a} \sqrt{\pi \sqrt{\text { area }}}
\end{gathered}
$$

この場合でも FDI, PDI と比較して高い相関が得られ なかった。さらに $\mathrm{ADI}$ 材には 2 種類の起点があることを 考慮するため, 起点が黒鉛であった ADI を○で囲んで 表した。しかしながら, 起点が黒鉛の場合と微小引け巣 の場合で，明確に分離することができない．従って Fig. 4 および Fig. 5 の検討から ADI 材のばらつきが FDI, PDI 材と比較して大きいことを説明することはできず， 以下では ADI 材の持つ特性の一つとして取り扱う。

\section{$3 \cdot 2$ 引張疲労破壊}

Fig. 6 , Fig. 7 にき裂発生寿命 $N_{i}$, き裂進展寿命 $N_{p 1}$, $N_{p 2}$ 扣よび破断寿命 $N_{f}$ の各寿命分布をワイブル確率紙

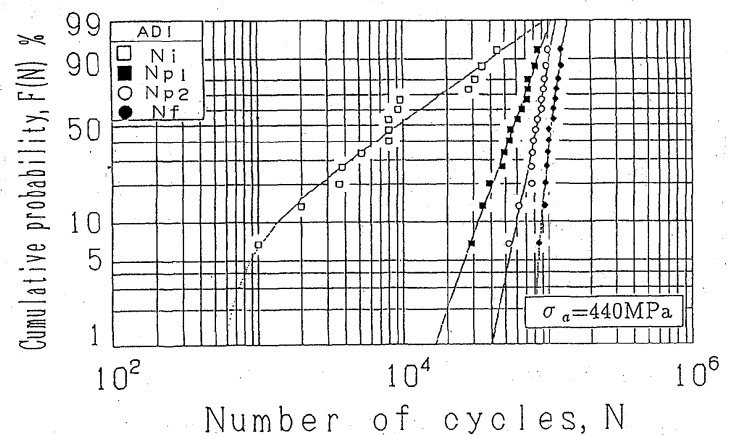

Fig. 6. Fatigue life distribution at high stress level.

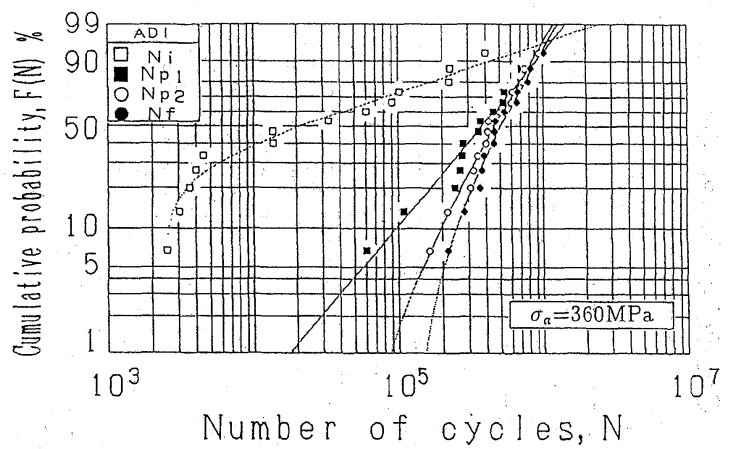

Fig. 7. Fatigue life distribution at low stress level.

上に示した.

また，得られたワイブル母数とその他の統計量を Table IVに示した.

き裂発生寿命は，特に低応力側ではばらつきが大きい が, 結果は 2 または 3 母数のワイブル分布で整理するこ とができた。

どちらのワイブル分布を用いたかは相関係数によって 決めたが, $360 \mathrm{MPa}$ の $N_{p 1}$ と $440 \mathrm{MPa}$ の $N_{p 2}$ を除いては 3 母数で表示した.

き裂の発生から破断に至るまで，き裂長さが増加する に従って各寿命曲線の傾きが大きくなっていく．

すなわち，ばらつきの程度が縮小している。

高応力レベルが低応力レベルに比べてばらつきが小さ いことも合わせて，上のような傾向はFDI，PDI と同様 である。

\section{4 考察}

\section{$4 \cdot 1$ 各寿命分布の確率特性}

本研究では $1 \times 10^{5}, 5 \times 10^{5}$ の平均寿命を目標にし，

Table IV. Weibull parameters and other statistical parameters of each life in $\mathrm{ADI}$.

\begin{tabular}{|c|c|c|c|c|}
\hline & $\begin{array}{c}\text { Correlation } \\
\text { factor } \\
r\end{array}$ & $\begin{array}{c}\text { Mean } \\
\text { life } \\
\mu\end{array}$ & $\begin{array}{c}\text { Standard } \\
\text { deviation } \\
\sigma \\
\end{array}$ & $\begin{array}{c}\text { Variation } \\
\text { coefficient } \\
\eta \\
\eta\end{array}$ \\
\hline \multirow{2}{*}{$N_{i}$} & 0.9764 & $1.794 \times 10^{5}$ & $5.854 \times 10^{5}$ & 3.2641 \\
\hline & 0.9600 & $1.627 \times 10^{4}$ & $1: 989 \times 10^{4}$ & 1.2225 \\
\hline \multirow{2}{*}{$N_{p 1}$} & 0.9601 & $4.429 \times 10^{5}$ & $3.229 \times 10^{5}$ & 0,7290 \\
\hline & 0.9889 & $5.846 \times 10^{4}$ & $1.999 \times 10^{4}$ & 0.3419 \\
\hline \multirow{2}{*}{$N_{p 2}$} & 0.9821 . & $4.912^{5}$ & $2.507 \times 10^{5}$ & 0.5103 \\
\hline & 0.9513 & $8.172^{4}$ & $1.632 \times 10^{4}$ & 0.1997 \\
\hline \multirow[b]{2}{*}{$N_{f}$} & 0.9814 & $5.455^{5}$ & $2.552 \times 10^{5}$ & 0.4678 \\
\hline & 0.9675 & $1.058^{5}$ & $1.349 \times 10^{4}$ & 0.1275 \\
\hline
\end{tabular}

\begin{tabular}{c|c|c|c|c}
\hline Life & $\begin{array}{c}\text { Stress } \\
\text { amplitude } \\
{[\mathrm{MPa}]}\end{array}$ & $\begin{array}{c}\text { Shape } \\
\text { parameter } \\
\alpha\end{array}$ & $\begin{array}{c}\text { Scale } \\
\text { parameter } \\
\beta\end{array}$ & $\begin{array}{c}\text { Location } \\
\text { parameter } \\
\gamma\end{array}$ \\
\hline \multirow{2}{*}{$N_{i}$} & 360 & 0.3878 & $4.875 \times 10^{4}$ & $2.450 \times 10^{3}$ \\
\cline { 2 - 5 } & 440 & 0.7972 & $1.384 \times 10^{4}$ & $5.500 \times 10^{2}$ \\
\hline \multirow{2}{*}{$N_{p 1}$} & 360 & 1.3891 & $4.853 \times 10^{5}$ & - \\
\cline { 2 - 5 } & 440 & 3.0689 & $6.280 \times 10^{4}$ & $2.327 \times 10^{3}$ \\
\hline \multirow{2}{*}{$N_{p 2}$} & 360 & 1.8389 & $5.005 \times 10^{5}$ & $4.663 \times 10^{4}$ \\
\cline { 2 - 5 } & 440 & 5.8059 & $8.825 \times 10^{4}$ & - \\
\hline \multirow{2}{*}{$N_{f}$} & 360 & 1.7343 & $4.817 \times 10^{5}$ & $1.163 \times 10^{5}$ \\
\cline { 2 - 5 } & 440 & 2.8747 & $4.009 \times 10^{4}$ & $7.010 \times 10^{4}$ \\
\hline
\end{tabular}




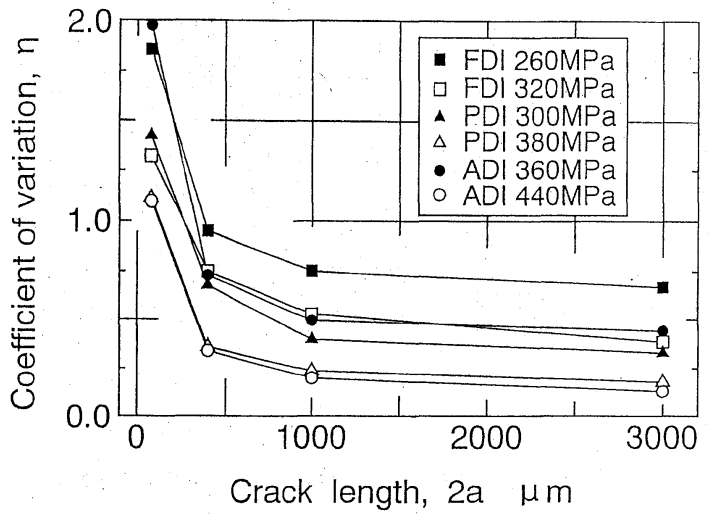

Fig. 8. Change of variation coefficient $\eta$ for crack length $2 a$.

さらに瘦労限度に対する応力振幅も供試材間でできるだ け一致するように配慮したが，実際上それらを厳密に一 致させることは困難である。また，ばらつきの程度には すでに述べたように応力振幅依存性が見られるので, 供 試材間で比較を行う場合には注意が必要である。

このような場合の各寿命のばらつきは，変動係数 $\eta=$

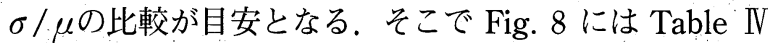
から得た $\eta$ の変化を示した. $N_{i}$ に対応する $\eta$ が最も大き い；すなわち，き裂の発生はき裂ごとのばらつきが大き い，そして，き裂が成長するに従ってクは小さくなって いくが, $N_{i}$ から $N_{p 1}$ の間にばらつきが大幅に減少してお り, $N_{p 1}$ 以降は減少も緩やかである. 従って, ADI の寿 命を評価するためには， $N_{p 1}$ に至るまでのき裂の進展を 詳細に観察しなければならない。

$\eta$ には応力振幅依存性が見られ，高応力側の方が小さ い.また供試材間の比較では, FDI が他の 2 材料に比べ

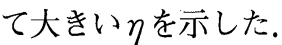

$\mathrm{ADI}$ 材のき裂の進展は，比較的長く成長したき裂にも 合体が進展初期と同じように生じていることが特徴的で あった."

また，FDI，PDI 材においては表面き裂の進展はその 経路，分岐などに微視組織の影響が強く現れているため に，早く発生したき裂が早く破断に至るとは限らない傾 向が観察された.

そこでADI 材についても各々のき裂について，発生か ら各進展段階を経て破断に至るまでの繰返し数の順位相 関係数 $Z$ の変化を, き裂長さ $2 a$ に対応して Fig. 9 に示 した. 順位相関係数 $Z$ は, 発生寿命 $N_{i}$ に寿命の短い順 に 1 から順番を付け，次に破断寿命 $N_{f}$ の寿命の短い順に 番号を付け，それらの順番の相関を見たもので，この值 が 1 に近いほど，すなわち順位相関が高いほど早く発生 したき裂が早く破断のき裂長さに到達することを表して いる.

低応力側ではき裂の短い段階で相関係数 $Z$ は 1 に近づ いてるが，高応力側では $2 a=1000 \mu \mathrm{m}$ 程度まで相関が 覀いという違いがあるものの，両方の応力レベルでき裂 発生寿命と破断寿命との順位相関係数は非常に低い値を
示している，すなわち，発生から破断までの過程で費や される繰返し数は，すべてのき裂で一様なものではない ことが分かり，き裂が発生した順番に破断に至る確率は 非常に低いといえる. 低応力側と高応力側の $Z$ の変化の 違いは，高応力では多数のき裂が発生し，き裂の合体が より頻繁に起こることが原因と考えられる。な抏，この ようなことは FDI, PDIについてもいえる.

Fig. 10 にき裂進展速度 $d a / d N$ とき裂半長 $a$ の関係を 示した．低応力側の $d a / d N$ は初期の大きなばらつき以 降は速やかに収束しているのに対して, 高応力側では破 断に至るまでばらつきが大きいことが分かる。このこと は上述の $Z$ が破断直前まで 1 に近づかないことに対応し ている。

\section{$4 \cdot 2$ 初期き裂長さからの寿命評価}

以上のことから，ADI 材のき裂の発生を定量的に捉え ることが困難で，その上き裂発生寿命の分布が破断寿命 の分布にはそのまま結びついていないことが明らかとな った。従って ADI 材の寿命評価を簡便に行うためには， き裂発生寿命に代わる基準が必要である. Fig. 10 に示 したき裂進展曲線では，高応力レべルの場合， $d a / d N$ は 增減を繰返しながらき裂半長の増加に伴って全体として 増加している。低応力レベルでは $d a / d N$ は一度減少し, その後増加，収束している，従ってこの極小值以降の進 展寿命は，き裂進展速度とき裂長さの関係から簡単に求

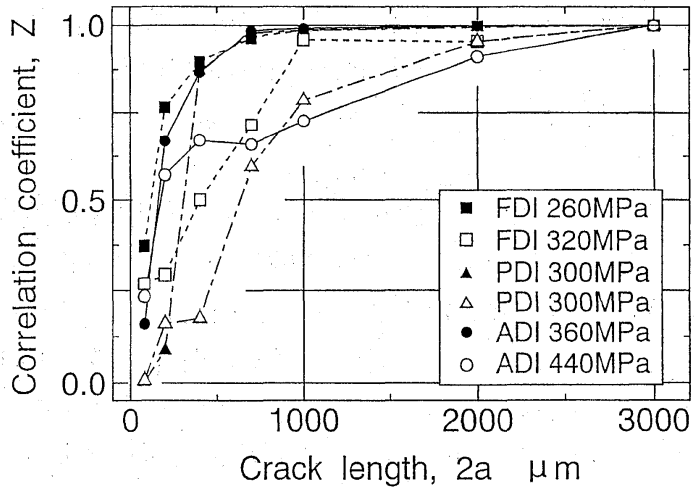

Fig. 9. Change of correlation coefficient $Z$ for crack length $2 a$.

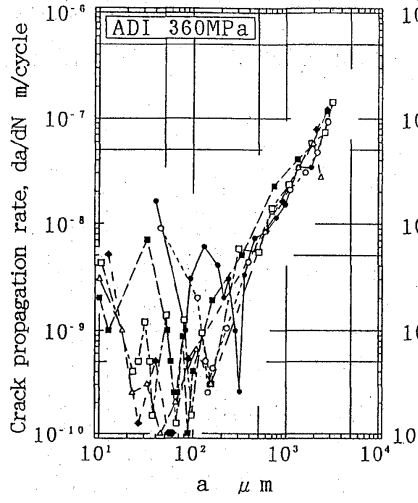

(a) Low stress level

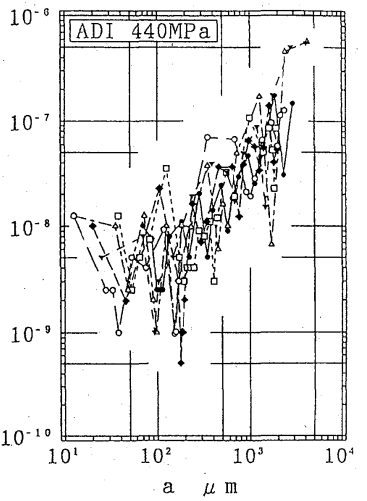

(b) High stress level
Fig. 10. Difference in crack propagation behavior between two stress levels. 


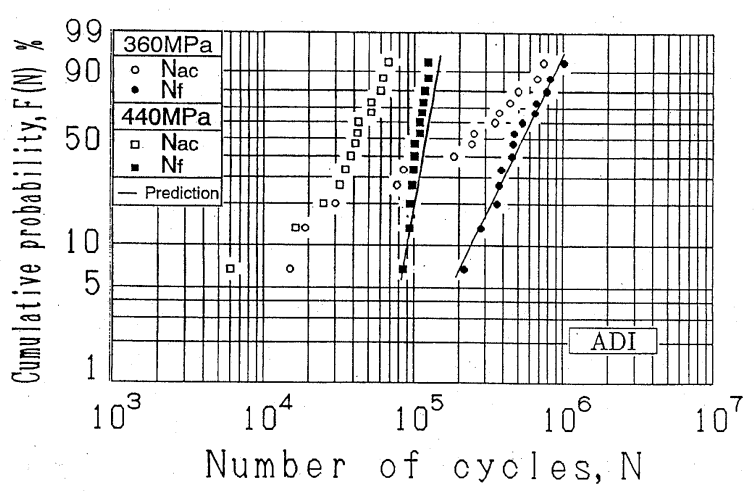

Fig. 11. Weibull plots of $N_{a c}$ and $N_{f}$.

めることができると考えられる，そこで， $d a / d N$ の極小 值を示す際のき裂長さ $2 a_{c}$ を調べたところ, $\mathrm{ADI}$ 材の場 合, 平均 $215 \mu \mathrm{m}$ であった. FDI, PDI についても調べ たところ，それぞれ $2 a_{c}=205,171 \mu \mathrm{m}$ であったので， ここでき裂長さが $200 \mu \mathrm{m}$ に達した時の寿命を $N_{a c}$ と定 義する。このときの寿命分布を求めて，ワイブル確率紙 上で整理する.と Fig. 11のようになる.

Fig. 10 扎よび Fig.11 から分かるように, $2 a=200 \mu \mathrm{m}$ に達しない時点では $d a / d N$ のばらつきは非常に大きか つたものの, $2 a=200 \mu \mathrm{m}$ の寿命は 1 つのワイブル分布で 表すことが可能である

$2 a_{c}=200 \mu \mathrm{m}$ までに，き裂進展速度が大きく増減しだ んだんと極小值に近づいていく原因は，各種き裂閉口や き裂の進展モードの変化など幾つか考えることができる が， $N_{a c}$ はこれらの複雑な影響を全て包含して 1 つの分布 で表されるために，非常に利便性がよい.

一方 Fig. 10 の $d a / d N-a$ 関係から, $2 a=200 \mu \mathrm{m}$ 以上の き裂に対して応力の影響を考慮してき裂長さを $\Delta \sigma_{a} \sqrt{\pi a}$ で再整理した結果が Fig. 12 である。このデータを一本 の直線で回帰して, $2 a=200 \mu \mathrm{m} \sim 3000 \mu \mathrm{m}$ の ADI 材の き裂伝ぱ則を得た。 以上から, $\mathrm{ADI}$ 材の破断寿命は $2 a$ $=200 \mu \mathrm{m}$ までの寿命 $N_{a c}$ と以降の伝ぱ則で表すことがで きる. $N_{a c}$ の分布を基にして，それぞれのき裂に対して $2 a=200 \mu \mathrm{m} \sim 3000 \mu \mathrm{m}$ の繰返し数をき裂伝ぱ則から求 め，破断寿命を推定した結果を Fig. 13 に示した. Fig. 13では， $N_{a c}$ に早く到達したき裂は早く破断寿命に達し， 遅く $N_{a c}$ になったき裂は破断寿命も遅くなるために，予 測寿命に幅がある．高応力レベルでは実験值よりもばら つきが大きくなったが，よく一致しているといえる範囲 である．低応力レべルでは，さらによく実験值と推定值 は一致している，従って，この寿命評価は実験結果をよ く表していると言える.

同様の推定を FDI, PDI についても行った結果も， Fig. 13 に示した.

いずれの DI 材も推定した破断寿命は実験のばらつき 範囲とよく一致しており，この破断寿命推定法が各種 DI 材に対して有効であることが分かる．またこの結果は， DI 材の破断寿命のばらつきが $2 a=100 \mu \mathrm{m}$ にき裂が成長 するまでの寿命のばらつきで支配されていることも示し

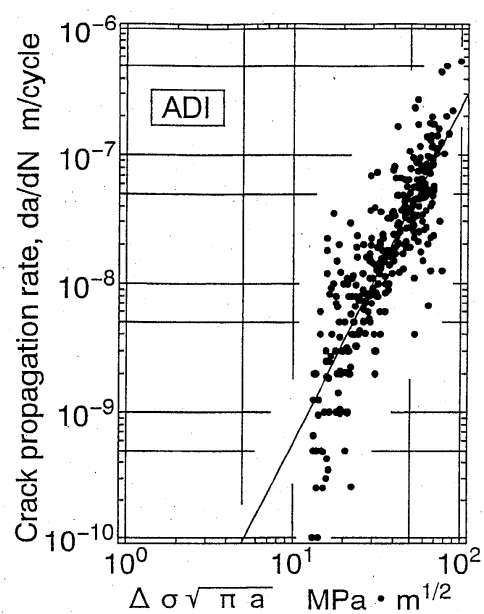

Fig. 12. A recurrent line of crack propagation behavior.

ており, DI 材の微小き裂の発生と発生直後の進展をよ く理解する必要があるといえる。

\section{5 結言}

高強度, 高じん性で各種機械構造用部材として有用視 されているオーステンパ処理球状黒鉛鋳鉄 ADI を用い て，回転曲げによる高サイクル疲労試験を実施した。

表面微小き裂の発生・進展挙動および発生から進展， 破断に至る各寿命を統計的に検討した結果をまとめて， 以下に示した。

(1) $\mathrm{ADI}$ の疲労き裂発生起点である微小引け巣ある いはドロスのような微小鋳造欠陥と黒鉛について，それ らの大きさは種類に関係なく 1 つのワイブル分布で表さ れたが，き裂発生寿命と起点寸法の関係には大きなばら つきがあった。

（2）き裂発生，進展，破断の各寿命分布をワイブル分 布で整理すると, き裂発生寿命はばらつきの程度が非常 に大きい。

ばらつきはき裂進展の初期に急激に小さくなった。

(3) $\mathrm{ADI}$ 材およびFDI，PDI 材の微小き裂は，発生し た順に破断に至る確率は極めて低いものであった。

(4) $d a / d N-a$ 関係の極小值に対応するき裂長さ $2 a$ は，供試材の基地によらず約 $200 \mu \mathrm{m}$ であった。

このときの寿命 $N_{a c}$ は 1 つのワイブル分布で表すこと

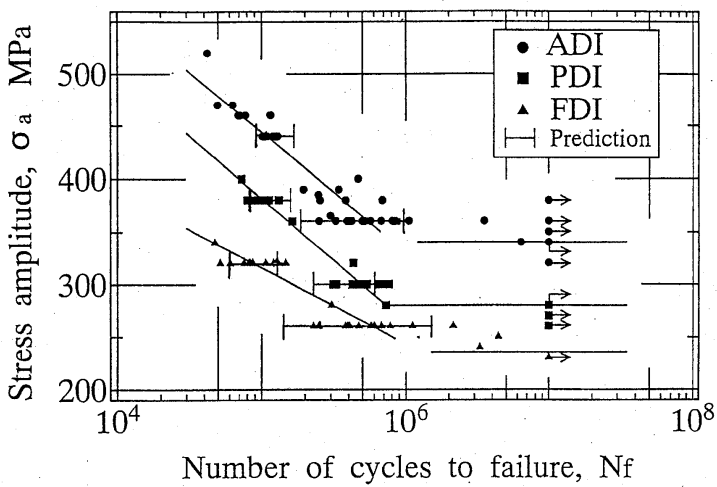

Fig. 13. Prediction of fatigue lives of ADI, PDI and FDI. 
ができ，き裂発生寿命に比べるとばらつきが非常に少 ない。

（5） $\mathrm{ADI}$ 材の破断寿命は $N_{a c}$ と以降の伝ぱで表すこと ができ, この方法によって推定した破断寿命は実験值と よく一致した. FDI, PDI 材でも同様の推定は実験のば らつきをよく表しており，DI 材の破断寿命のばらつき が $2 a=200 \mu \mathrm{m}$ までのばらつきで支配されていることを 明らかにした。

(平成 8 年11月26日 日本材料学会第23回疲労シンポジウムにて講演)

\section{参 考 文 献}

1）高橋良治, 熱処理, 22, 294，(1982).

2 ）小林俊郎, 山本浩喜, 鋳物, 59, 573 (1983).

3 ) 矢野 満, “鋳造材料の強度評価と材料力学の入門基礎
(球状黒鉛鋳鉄を中心として)”, 日本機械学会講習会教材, p.15 (1981).

4) 越智保雄, 石井 明, 佐々木茂美, 小西康哉, 日本機械 学会論文集, A-57, 1488 (1991).

5 ) 越智保雄, 石井 明, 佐々木茂美, 小西康哉, 日本機械 学会論文集，A-58，353（1992）。

6) 越智保雄, 石井 明, 佐々木茂美, 小方智寿, 小西康哉, 日本材料学会第7回破壊力学シンポジウム講演論文集, p.31 (1993).

7 ）越智保雄, 石井 明, 佐々木茂美, 小西康哉, 日本機械 学会論文集，A-58，965（1992）。

8) 村上敬宜, 児玉昭太郎, 小沼静代, 日本機械学会論文集, A-54, 688 (1988).
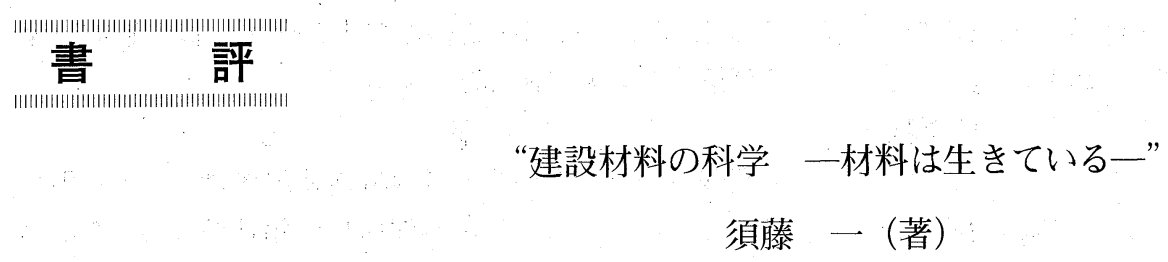

(1997 年、内田老鶴围、A5 判、278 ページ、定価 5000 円)

本書は，その主題にもあるように「建設材料」を「科学的」な側面から捉えたものである. 表紙には, 平成 7 年 1 月 17 日午前 5 時 46 分51.9秒に発生した兵庫県南部地震による阪神・淡路大震災で被害の象徴のように取り扱われ，建設分野の みならず，もの造りに携わる者にとっては忘れることのできない，また忘れてはならないピルツ橋の挿絵がある.

本書で対象となっている「建設材料」は多岐にわたって扔り, 岩石・鉱物材料, 鉄鋼材料, セメント・コンクリート 材料，アスファルト材料，木材・木質材料，ガラス材料，高分子材料が含まれている。これらは従来から使用されてい る材料であり，その性能は実績からはある程度確認されている場合もある。しかし，もともと複数の物質から構成される 材料なのであって, 複雑な組成により不明な点も多く，物質化学的な側面へのさらなる研究が必要とされている：これに 対して本書では，まず原子レベルでの物質構造の基本から記述し，続いて鋼材の変態，コンクリートの水和反応，高分 子材料の基本構造などについて説明してある。さらに，超硬合金，繊維強化コンクリート，高分子材料への充填剤・添 加剂をはじめ, 界面活性剤, 塗料・吹付材, 接着棛, 遮音・防音材料, 免震材料といった，よりマクロなレベルでの材 料の複合化についても言及してある.

すなわち，「科学的」に捉えるとは，各種材料がどのように構成されているかを分解・分析・解析・抽出することを意 味し，「建設材料」とは，ここではそれらの材料を加工し，複合化して組み立てた結果得られるシステムを表している。 そして，副題にある「材料は生きている」とは，各種材料を分解し，また一方では複合化することによって，必要な性能 を発揮すべく物性を変化させられる可能性，扰よびその必要性を表現しているものと思われる，なお，著者は，これら 2 つのハードウェア的側面のほかに，具現化した物体をどのように取り扱うかというソフトウェアの側面をあわせて，工学 が成り立つと述べている。

本書に目を通す場合，まずは各人の専門分野から初めてもよいし，興味のある別の分野に飛び込んでもよい。なぜな ら，本書は材料システムを対象としているからである。実際，「界面」や「接着」に関する記述は，現在ではどの分野で も興味の対象となるであろう。また，たとえば従来セメント・コンクリートの章に割り当てられることの多いアルカリ骨 材反応に関する記述が，「コンクリートに有害な鉱物」として岩石・鉱物材料の基本事項の章に記述されていることも面 白い.

以上のように本書は，各方面における専門技術者，研究者が力を合わせて開発に取り組む必要性を基本理念とし，そ の場合の基礎的な知識を与えてくれる，一方，材料の初心者に詨しても，各種材料がどのような組成・特性を持ち，そ れらがどのように組み合わされ利用されるかという一連の流れを, 盛り込まれた各種材料をそれぞれ例として学習するこ とができる。本書のページ数では多方面にわたる解説は十分でなく，もちろん著者もこのことは承知で思い切った省略を せざるをえなかったと思われるが, 要点が抽出された平易な記述のためどんどん読み進められ, 更なるステップアップの きっかけになろう。

(京都大学大学院工学研究科, 服部 篤史) 